\title{
News from the editors
}

\section{Chironomus newsletter changes name to CHIRONOMUS Journal of Chironomidae Research}

As of the next issue (No. 28, 2015) the newsletter changes name to CHIRONOMUS Journal of Chironomidae Research. This change will hopefully make it even more attractive to submit research articles to our journal and further increase the quality and readership of the content. We will continue to publish Short Communications and news items that are not necessarily subjected to peer-review. The journal will remain open access and free of page charges, and will continue to be indexed in the Directory of Open Access Journals and Google.

\section{Nomenclatorial acts to be registered in ZooBank}

Taxon names and nomenclatorial acts are listed in the open access registry ZooBank (www.zoobank.org), to ensure free availability of this information with links to authors and publications. The newsletter and the coming CHIRONOMUS Journal of Chironomidae Research has started to register all published nomenclatorial acts from the journal in ZooBank starting from No. 26, 2013.

Alyssa M. Anderson, Torbjørn Ekrem, Peter H. Langton 